\title{
Pengembangan Media Video Untuk Meningkatkan Pengetahuan dan Sikap Ibu Tentang Tumbuh Kembang Anak di Wilayah Kerja Puskesmas Jagoi babang Kalimantan Barat
}

\author{
Yopita Triguno $^{1}$, Supahar $^{2}$, Luh Ayu Purnami ${ }^{3}$
}

\begin{abstract}
ABSTRAK
Latar Belakang : Tumbuh kembang anak merupakan proses yang terjadi pada kehidupan anak, sehingga membutuhkan perhatian yang khusus. $\mathrm{Di}$ Indonesia terdapat $7,51 \%$ prevalensi penyimpangan perkembangan. Tujuan Penelitian : Mengetahui pengaruh media video untuk meningkatkan pengetahuan dan sikap ibu tentang tumbuh kembang anak di wilayah kerja puskesmas Jagoi Babang. Metode Penelitian : Penelitian ini merupakan jenis penelitian Quasi Eksperimen dengan rancangan pre test-post test group design. Penelitian dilakukan diwilayah kerja puskesmas jagoi babang tanggal 24 juli 2019. Sampel penelitian 53 orang masing-masing kelompok media video, leaflet dan PPT. Teknik pengambilan sampel simpel random sampling. Variabel independen yaitu media video, variabel dependen yaitu pengetahuan dan sikap. Instrumen penelitian menggunakan kuesioner. Analisis pengaruh menggunakan manova dan uji beda menggunakan anova. Hasil Penelitian : Penyuluhan menggunakan media video, leaflet dan power point berpengaruh pada pengetahuan dan sikap dengan $p$-value $0,00<0,05$. Penyuluhan menggunakan video secara signifikan mempengaruhi peningkatan pengetahuan sebesar $88 \%$. Penyuluhan menggunakan video secara signifikan mempengaruhi peningkatan sikap sebesar $76 \%$. Tidak ada pengaruh yang bermakna dari variabel luar terhadap pengetahuan dan sikap tentang tumbuh kembang anak. Kesimpulan : Ada pengaruh penyuluhan menggunakan media terhadap pengetahuan dan sikap ibu tentang tumbuh kembang anak dengan $p$-value $0,00<0,05$. Bidan puskesmas dapat memberikan penyuluhan mengenai tumbuh kembang anak menggunakan media video agar pengetahuan dan sikap ibu semakin optimal.
\end{abstract}




\section{PENDAHULUAN}

Tumbuh kembang merupakan proses yang terjadi pada kehidupan anak. Tumbuh kembang anak harus dipantau dari sedini mungkin karena akan berpengaruh pada usia selanjutnya. Menurut Kementerian Kesehatan RI, (2014) tumbuh kembang anak usia 0-5 tahun sangatlah penting, karena merupakan masa pertumbuhan dan perkembangan yang paling pesat pada otak manusia.

Di Indonesia sendiri terdapat $7,51 \%$ prevalensi penyimpangan perkembangan meskipun saat ini masih belum memiliki data nasional mengenai perkembangan/gangguan perkembangan pada balita. Menurut WHO, (2018), berdasarkan jenis kecacatan perkembangan anak, Indonesia berada di peringkat ke-9 untuk disabilitas intelektual, peringkat ke-5 untuk autisme. Ikatan Dokter Anak Indonesia (IDAI), (2014) menyebutkan bahwa sekitar $5 \%$ sampai $10 \%$ anak diperkirakan mengalami keterlambatan perkembangan. Hasil penelitian dari Tjandrajani, et.al, (2012) menunjukkan bahwa dari 604 pasien didapatkan $187(30,9 \%)$ pasien dengan keterlambatan perkembangan umum tanpa penyakit penyerta meliputi gangguan bicara $44(46,8 \%)$, perkembangan gerakan terlambat29 $(30,9 \%)$, dan tanpa keluhan 12 (12,8\%). Menurut Kemenkes RI, (2018) sebesar 17,7\% anak mengalami gizi buruk+gizi kurang, 30,8\% mengalami stunting, dan 10,2\% sangat kurus+kurus. Berdasarkan Kemenkes RI, (2018), di Kalimantan Barat kejadian gizi buruk dan gizi kurang usia 0-59 bulan sebesar $23,8 \%$, kejadian sangat pendek dan pendek usia 0-59 sebesar 33.3\%. Sedangkan di Kabupaten Bengkayang pada tahun 2017 sebesar 31,26\% balita mengalami stunting dan terdapat sebanyak 16 kasus gizi buruk. Di wilayah kerja Puskesmas Jagoi sendiri pada tahun 2018 terdapat 7 kasus gizi buruk, 69 kasus gizi kurang, 51 kasus sangat pendek, 13 kasus sangat kurus dan terdapat 8 kasus keterbelakangan mental.

Studi pendahuluan dilakukan di wilayah kerja Puskesmas Jagoi Babang kemudian di dapat 1 desa yang memiliki jumlah anak usia 0-59 bulan paling banyak dan terdapat kasus gangguan tumbuh kembang. Setelah itu dilakukan wawancara pada 10 ibu yang memiliki 
balita antara usia 0-59 bulan, sebanyak 9 ibu mengatakan tidak mengetahui tentang tumbuh kembang, dan 1 ibu mengatakan tahu sedikit karena pernah membaca di buku KIA. Semua ibu tersebut tidak pernah memeriksakan tumbuh kembang anaknya ke pelayanan kesehatan.

Berdasarkan Peraturan Menteri Kesehatan Republik Indonesia Nomor 25 Tahun 2014, orang tua memiliki peran aktif dalam upaya kesehatan anak yaitu melakukan perawatan pada anak, memberi perlindungan pada anak, dan berperan aktif dalam memberikan stimulasi tumbuh kembang pada anak. Orang tua khususnya ibu memiliki peran yang sangat penting pada tahap pertumbuhan dan perkembangan anaknya khususnya pada usia 0-6 tahun. Upaya untuk meningkatkan pengetahuan dan sikap keluarga, khususnya ibu dapat dilakukan dengan beberapa cara. Salah satu faktor yang mempengaruhi yaitu media massa/ informasi. Sejalan dengan penelitian Latifah, (2012) bahwa orang tua yang diberi penyuluhan berpengaruh positif terhadap peningkatan pengetahuan ibu tentang tumbuh kembang balita dengan skor pengetahuan ibu yang meningkat dari 11,94 menjadi 15,78. Diharapkan dengan informasi yang diberikan tentang tumbuh kembang maka dapat meningkatkan pengetahuan ibu tentang tumbuh kembang pada anak sesuai dengan usianya sehingga dengan pengetahuan yang baik tersebut dapat mempengaruhi sikap ibu terhadap kesediaan untuk memeriksakan tumbuh kembang anaknya kepelayanan kesehatan. Maka dari itu peneliti ingin membuat inovasi dalam memberikan pendidikan kesehatan kepada masyarakat melalui media video. Media video dapat menstimulasi indera pendengaran dan penglihatan sehingga hasil yang diperoleh lebih maksimal. Hal ini telah dibuktikan oleh penelitian yang dilakukan oleh Zakariya, (2017) menunjukkan bahwa ada peningkatan yang signifikan terhadap pengetahuan dan sikap ibu setelah diberikan pendidikan kesehatan dengan media audiovisual. Oleh karena itu peneliti ingin mengembangkan media video untuk meningkatkan pengetahuan dan sikap ibu tentang tumbuh kembang anak. Berdasarkan gambaran di atas, maka peneliti ingin mengetahui bagaimana pengaruh media video untuk meningkatkan pengetahuan dan sikap ibu tentang tumbuh kembang anak di wilayah kerja Puskesmas Jagoi Babang tahun 2019?

\section{METODE PENELITIAN}


Jenis penelitian ini adalah Quasi Experimental Design dengan menggunakan pretestposttest group design. Penelitian dilakukan di wilayah kerja Puskesmas Jagoi Babang. Teknik pengambilan sample dengan simple random sampling dengan kriterian inklusi dan ekslusi . Jumlah sample sebanyak 159 sample yang terdiri 3 kelompok media yaitu video, leaflet dan power point. Variabel independen pada penelitian ini media video tentang tumbuh kembang, variabel dependen adalah pengetahuan dan sikap, dan Variabel luar adalah umur, pendidikan, pekerjaan, dan paritas. Uji analisis statistik mengunakan uji manova dan anova.

\section{HASIL PENELITIAN}

\section{a. Deskripsi Data}

Tabel 1

Distribusi Karakteristik Responden Berdasarkan Usia, Pendidikan dan Pekerjaan pada lbu

\begin{tabular}{|c|c|c|c|c|c|c|c|c|c|}
\hline \multirow{3}{*}{ Karakteristik } & \multicolumn{6}{|c|}{ Media } & \multirow{2}{*}{\multicolumn{2}{|c|}{ Total }} & \multirow{3}{*}{$\begin{array}{c}P \\
\text { value }\end{array}$} \\
\hline & \multicolumn{2}{|c|}{ Video } & \multicolumn{2}{|c|}{ Leaflet } & \multicolumn{2}{|c|}{ PPT } & & & \\
\hline & $\mathrm{N}$ & $\%$ & $\mathrm{~N}$ & $\%$ & $\mathrm{n}$ & $\%$ & $\mathrm{~N}$ & $\%$ & \\
\hline \multicolumn{10}{|l|}{ Umur } \\
\hline$<20$ tahun & 6 & 3,8 & 9 & 5,7 & 2 & 1,3 & 17 & 10,8 & \multirow{3}{*}{5,573} \\
\hline 20-35 tahun & 44 & 27,7 & 39 & 24,5 & 46 & 28,9 & 129 & 81,1 & \\
\hline$>35$ tahun & 3 & 1,9 & 5 & 3,1 & 5 & 3,1 & 13 & 8,1 & \\
\hline \multicolumn{10}{|l|}{ Pendidikan } \\
\hline Dasar & 10 & 6,3 & 13 & 8,2 & 11 & 6,9 & 34 & 21,4 & \multirow{3}{*}{0,524} \\
\hline Menengah & 43 & 27,0 & 40 & 25,2 & 42 & 26,4 & 125 & 78,6 & \\
\hline Tinggi & 0 & 0 & 0 & 0 & 0 & 0 & 0 & 0 & \\
\hline \multicolumn{10}{|l|}{ Pekerjaan } \\
\hline Bekerja & 5 & 3,1 & 7 & 4,4 & 3 & 1,9 & 15 & 9,4 & \multirow{3}{*}{1,767} \\
\hline Tidak Bekerja & 48 & 30,2 & 46 & 28,9 & 50 & 31,4 & 144 & 90,5 & \\
\hline Jumlah & 53 & 100 & 53 & 100 & 53 & 100 & 159 & 100 & \\
\hline
\end{tabular}

\section{b. Pengujian Hipotesis}

Hasil nilai yang dikumpulkan dalam penelitian ini, dilakukan pengolahan dan analisa data dengan menggunakan metode statistik. Adapun hasil olah data sebagai berikut :

\section{Manova}


Hasil uji beda dapat di interprestasikan bahwa harga F untuk Wilks' Lambda, memiliki nilai signifikan yang lebih kecil dari 0,05 yaitu 0,00 . Jadi, terdapat perbedaan pengetahuan dan sikap ibu tentang tumbuh kembang anak menggunakan 3 media (video, leaflet dan power point). Hasil tersebut dapat dilihat pada tabel dibawah ini.

Tabel 2 Multivariat Test

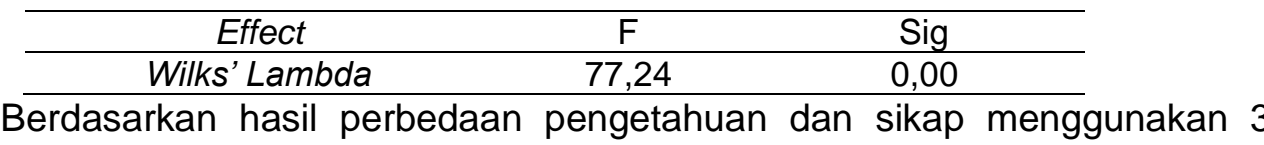
media yang di peroleh dapat di interprestasikan bahwa ada pengaruh media video terhadap pengetahuan ibu tentang tumbuh kembang anak memberikan harga $F$ sebesar 171,81 dengan signifikan 0,00. Selanjutnya pengaruh media video terhadap sikap ibu tentang tumbuh kembang anak memberikan harga $F \quad 77,22$ dengan signifikansi 0,00. Hasil tersebut dapat dilihat pada tabel dibawah ini.

Tabel 3 Test Between-Subjects Effects

\begin{tabular}{ccc}
\hline Variabel & $\mathbf{F}$ & Sig \\
\hline Pengetahuan & 171,81 & 0,00 \\
\hline Sikap & 77,22 & 0,00 \\
\hline
\end{tabular}

Dari hasil analisis diketahui bahwa faktor umur, pendidikan, pekerjaan dan paritas di analisa menggunakan uji mancova test didapat hasil penelitian yaitu umur dengan $p$ value $(0,23$ dan 0,27$)$, pendidikan dengan $p$ value $(0,54$ dan 0,63$)$, pekerjaan dengan $p$ value $(0,78$ dan 0,44$)$ dan paritas dengan $p$ value $(0,55$ dan 0,46$)$. Kesimpulan yang didapat dari hasil tersebut yaitu tidak ada pengaruh yang bermakna dari variabel luar terhadap pengetahuan dan sikap ibu tentang tumbuh kembang anak dengan $p$ value $>0,05$. Hasil selengkapnya dapat dilihat pada tabel dibawah ini.

Tabel 4 Faktor usia, pendidikan, pekerjaan dan paritas terhadap peningkatan pengetahuan dan sikap ibu menggunakan media video, leaflet dan power point

\begin{tabular}{cccc}
\hline $\begin{array}{c}\text { Variabel } \\
\text { Dependen }\end{array}$ & Terhadap & F & P value \\
\hline \multirow{2}{*}{ Umur } & Pengetahuan & 1,45 & 0,23 \\
\cline { 2 - 4 } & Sikap & 1,29 & 0,27 \\
\hline \multirow{2}{*}{ Pendidikan } & Pengetahuan & 0,37 & 0,54 \\
\cline { 2 - 4 } & Sikap & 0,22 & 0,63 \\
\hline Pekerjaan & Pengetahuan & 0,07 & 0,78 \\
\hline & http://ejournal.stikesbuleleng.ac.id/index.php/Midwinerslion $\mid 188$
\end{tabular}




\begin{tabular}{lccc}
\hline & Sikap & 0,58 & 0,44 \\
\hline \multirow{2}{*}{ Paritas } & Pengetahuan & 0,70 & 0,55 \\
\cline { 2 - 4 } & Sikap & 0,85 & 0,46 \\
\hline
\end{tabular}

\section{Anova}

Pengaruh Penyuluhan dengan Media Video Tentang Tumbuh Kembang Anak Terhadap Pengetahuan Ibu

Hasil uji pengaruh penyuluhan menggunakan media video dapat diinterprestasikan bahwa nilai $F=1227,988$ dengan nilai Sig $=0,00<0,05$ artinya terdapat interaksi yang menunjukkan bahwa perubahan skor pre test menuju post test nilai pengetahuan pada ketiga kelompok adalah berbeda secara signifikan. Nilai partial eta squared yaitu 0,88 yang artinya terjadi interaksi antara tahapan peningkatan pre test-post test dengan kelompok video, leaflet dan power point meningkat yaitu $88 \%$. Hasil selengkapnya dapat dilihat ditabel dibawah ini.

Tabel 5 Test Of Within-Subject Effects Pengetahuan

\begin{tabular}{cccc}
\hline Effect & F & Sig & Partial Eta Squared \\
\hline Greenhouse-Geisser & 1227,988 & 0,00 & 0,88 \\
\hline
\end{tabular}

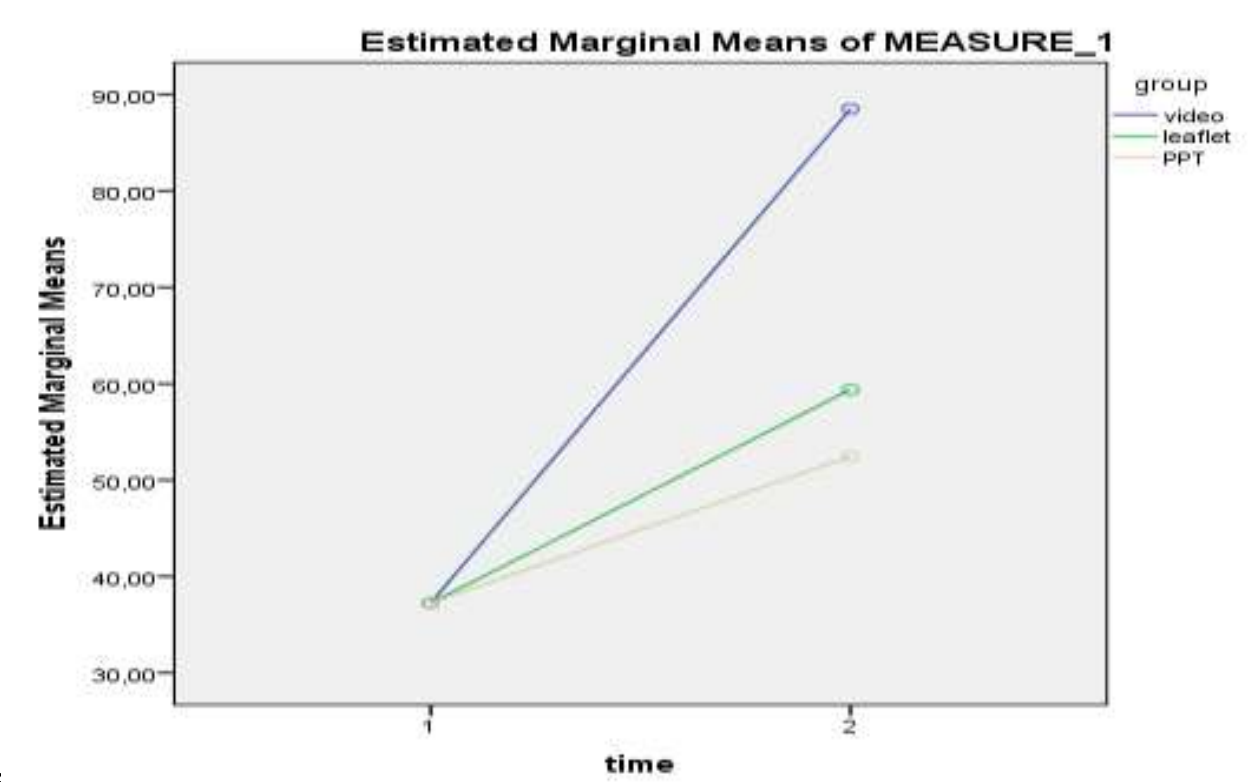

vid $\epsilon$

Pengaruh Penyuluhan dengan Media Video Tentang Tumbuh Kembang Anak Terhadap Sikap Ibu 
Hasil dari uji pengaruh penyuluhan dengan media video dapat diinterprestasikan bahwa nilai $F=753,073$ dengan nilai $\mathrm{Sig}=0,00<0,05$ artinya terdapat interaksi yang menunjukkan bahwa perubahan skor pre test menuju post test nilai sikap pada ketiga kelompok adalah berbeda secara signifikan. Nilai partial eta squared yaitu 0,82 yang artinya terjadi interaksi antara tahapan peningkatan pre test-post test dengan kelompok video, leaflet dan power point meningkat yaitu $82 \%$. Hasil selengkapnya dapat dilihat pada tabel dibawah ini.

Tabel 6 Test Of Within-Subject Effects Sikap

\begin{tabular}{cccc}
\hline Effect & $\mathrm{F}$ & Sig & Partial Eta Squared \\
\hline Greenhouse-Geisser & 753,073 & 0,00 & 0,82 \\
\hline
\end{tabular}

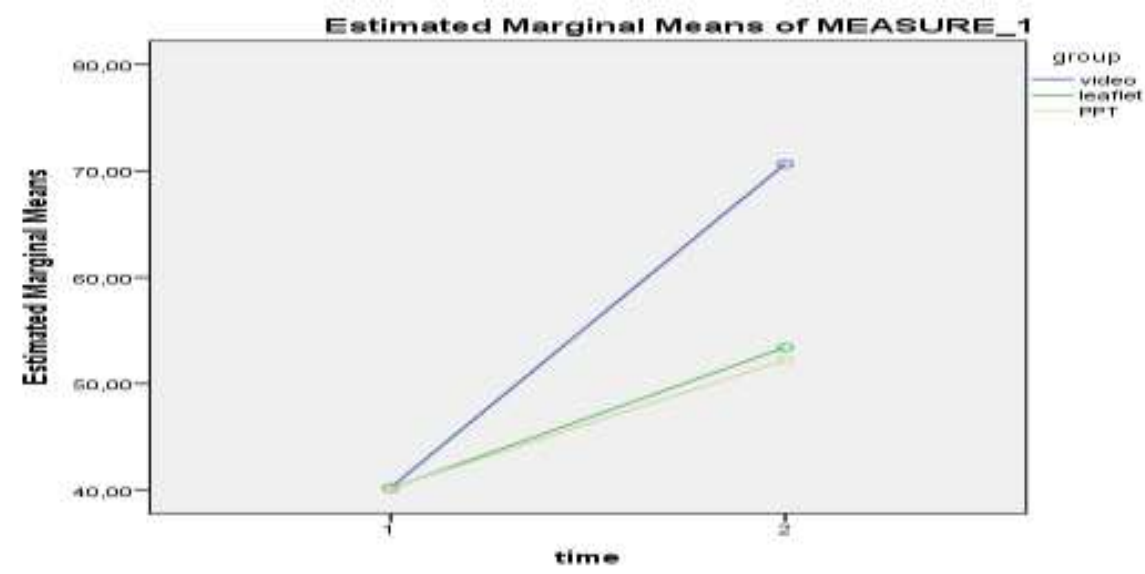

Berdasarkan gambar kurva dapat disimpulkan bahwa pemberian media video lebih meningkatkan sikap ibu tentang tumbuh kembang anak.

\section{DISKUSI}

\section{Pengaruh Penyuluhan dengan Media Video Terhadap Pengetahuan dan Sikap Ibu Tentang Tumbuh Kembang Anak}

Berdasarkan hasil analisis multivariat test pada tabel 2 dapat di interprestasikan bahwa harga $\mathrm{F}$ untuk wilks' lambda memiliki nilai signifikan yang lebih kecil dari 0,05 yaitu 0,00. Sehingga dapat disimpulkan bahwa ada perbedaan yang signifikan terhadap pengetahuan dan sikap ibu tentang tumbuh kembang anak menggunakan media video, leaflet, dan power point. Berdasarkan tabel 3 dapat diinterprestasikan bahwa pengaruh media video terhadap pengetahuan ibu tentang tumbuh kembang anak memberikan nilai signifikan 
sebesar 0,00 sedangkan pengaruh media video terhadap sikap ibu tentang tumbuh kembang anak memberikan nilai signifikan sebesar 0.00. Hal ini menunjukkan bahwa terdapat perbedaan peningkatan pengetahuan dan sikap ibu tentang tumbuh kembang anak yang diakibatkan oleh pemberian penyuluhan kesehatan menggunakan media video.

Berdasarkan pada gambar 2 dan 3 pada kelompok media video terjadi peningkatan pengetahuan secara signifikan lebih dari $50 \%$ sedangkan untuk pengingkatan sikap mengalami peningkatan lebih dari $30 \%$ pada post test. Sedangkan pada kelompok media leaflet dan power point mengalami peningkatan pengetahuan yang tidak jauh berbeda yaitu diatas $20 \%$ dan $15 \%$ dan untuk peningkatan sikap lebih dari $12 \%$ pada post test yang tidak lebih besar dari peningkatan pada media video.

Pengembangan yang dilakukan dalam media video tentang tumbuh kembang yaitu meliputi pengertian pertumbuhan dan perkembangan, cara mengetahu pertumbuhan dan perkembangan, fakor yang mempengaruhi tumbuh kembang, tahapan tumbuh kembang, gangguan pada tumbuh kembang dan deteksi dini tumbuh kembang. Pengembangan yang dilakukan tersebut adalah berusaha menyempurnakan video-video tentang tumbuh kembang yang sudah ada. Media video yang dikembangkan peneliti lebih lengkap pada bagian tahapan perkembangan dan disertai dengan gangguan tumbuh kembang serta deteksi dini yang dapat dilakukan. Pengembangan yang lebih lengkap ini terbukti meningkatkan pengetahuan dan sikap ibu tentang tumbuh kembang anak. Hal ini dikarenakan isi materi didalam video tersebut diberikan berurutan dan lengkap dari hal dasar yang harus diketahui ibu sampai bagaimana ibu harus bersikap. Bahasa didalam video yang dikembangkan pun dibuat mudah dipahami orang awam. Dilanjutkan dengan sudah terujinya oleh ahli pula sehingga dipastikan sangat layak bagi responden yaitu para ibu. Menggunakan media video yang dikembangkan tersebut sebagai media penyuluhan didapat hasil yang lebih efektif dikarenakan melibatkan 2 indera yaitu pendengaran dan penglihatan dibandingkan dengan media leaflet dan power point. Media video yang dikembangkan untuk penelitian ini didesain sebaik mungkin dengan menggunakan model gerak dan kalimat yang semenarik mungkin sehingga meningkatkan 
keinginan responden untuk memperhatikan informasi apa saja yang diberikan dalam tayangan video yang ditampilkan. Kemudian diperjelas kembali dengan penjelasan dari pemberi penyuluhan, maka dapat meningkatkan pengetahuan responden. Sejalan dengan penelitian Mutanda (2016) bahwa ibu yang diberi edukasi dengan menonton video menyatakan pengetahuannya meningkat karena video mudah dipahami serta ibu sangat menyukai edukasi menggunakan video. Sejalan juga dengan penelitian Ervina (2012) bahwa media video menjadi media yang efektif dalam menyampaikan informasi kepada masyarakat. Hal ini sejalan dengan teori kerucut pengalaman Edgar Dale menyatakan bahwa seseorang yang ikut terlibat dalam visual (berupa gambar, video, demonstasi) maka yang diingat sebesar 30\%. Pendapat lain juga disampaikan dalam penelitian Zakariya (2017) bahwa edukasi menggunakan media video terbukti efektif dalam meningkatkan pengetahuan dan sikap ibu hamil. Hal tersebut terbukti dari kelompok intervensi yang diberikan pendidikan kesehatan dengan media video sebelumnya 53\% responden memiliki pengetahuan baik setelah intervensi menjadi $100 \%$ berpengetahuan baik. Sehingga dapat disimpulkan bahwa peningkatan pengetahuan dan video dipengaruhi oleh adanya bantuan media yang mempermudah responden dalam mengingat materi yang diberikan.

Media video yang digunakan dala penelitian ini sangat efektif digunakan sebagai media untuk melakukan penyuluhan dikondisi yang tidak kondusif sekalipun. Hal ini terbukti ketika dilakukan penelitian pada kelompok media video yang dilakukan sore hari dan terdapat ibu-ibu yang membawa anaknya dan sedikit repot tetapi pengetahuan dan sikapnya lebih baik dari kelompok media leaflet dan power point yang meskipun penyuluhan dilakukan malam hari dan tidak terdapat gangguan dari anak-anak saat berlangsungnya penyuluhan.

Berdasarkan hasil penelitian dan pembahasan diatas dapat ditarik kesimpulan bahwa penyuluhan kesehatan menggunakan media video dapat meningkatkan pengetahuan dan sikap ibu tentang tumbuh kembang anak. Hal ini terbukti dengan adanya perbedaan peningkatan pengetahuan dan sikap ibu yang diakibatkan oleh pemberian penyuluhan kesehatan dengan media video, meskipun pada penyuluhan dengan media leaflet dan power 
point juga mengalami perbedaan peningkatan setelah diberikan penyuluhan tetapi nilai tersebut masih jauh lebih tinggi dibandingkan dengan menggunakan media video. Media video dalam penelitian ini meningkatkan pengetahuan dan sikap lebih baik dikarenakan berisi materi yang lebih lengkap dari sebelumnya, lebih memberikan suasana yang "hidup" karena terdapat animasi, sehingga penampilannya lebih menarik dan memperlihatkan suatu proses tertentu secara lebih nyata. Sehingga dapat disimpulkan bahwa media video, leaflet dan power point sama-sama dapat meningkatkan pengetahuan dan sikap ibu tentang tumbuh kembang anak baik diberikan secara bersama-sama maupun secara sendiri-sendiri.

\section{KESIMPULAN}

Dari hasil penelitian dapat disimpulkan bahwa ada pengaruh media video tentang tumbuh kembang anak terhadap pengetahuan dan sikap dengan nilai signifikan ( $p$-value = $0,00)$. Tidak ada pengaruh variabel luar terhadap pengetahuan dan sikap ibu tentang tumbuh kembang.

\section{UCAPAN TERIMAKASIH}

Peneliti mengucapkan terimakasih kepada Program Studi Magister Terapan Kebidanan STIKES Guna Bangsa Yogyakarta yang telah memberikan izin untuk melakukan penelitian, dan ucapan terima kasih juga kepada lbu. Dr. Supahar.,M.Si dan Dr.dr.H.M. Any Ashari, SpOG (K) selaku pembimbing atas bantuan yang berharga dalam penyusunan naskah penelitian ini.

\section{DAFTAR PUSTAKA}

Dinas kesehatan (2017) Profil kesehatan provinsi kalimantan barat. Pontianak, Kalimantan Barat.

IDAI (2014) Pedoman Penatalaksanaan. Stimulasi, Deteksi, dan Intervensi Dini Tumbuh Kembang Anak di Tingkat Pelayanan Kesehatan Dasar. Jakarta: Bakti husada.

Kemenkes RI (2018) Data dan Informasi, Profil Kesehatan Indonesia. Jakarta.

Kementerian Kesehatan RI (2014) 'Permenkes RI No 75 Tahun 2014 tentang puskesmas.' Available at: Depkes RI.

Latifah Abdurahmah (2012) 'PENGARUH METODE DISKUSI KELOMPOK FUNGSIONAL TERHADAP PENGETAHUAN IBU TENTANG TUMBUH KEMBANG BALITA (Studi Kasus di Posyandu Margiraha yu IV Desa Pekalongan Kecamatan Bojongsari Kabupaten Purbalingga ', $1(2)$. 
Mabud (2012) 'Pengaruh Kegiatan Penyuluhan Dalam Pelayanan Kesehatan (PKPR) Terhadap Pengetahuan Dan Sikap Remaja Tentang Seks Pranikah Di SMAN 1 Labula Dalam Kabupaten Siak Sri Indrapura', Of Family and Reproductive Health, 1.

Taurai Mutanda, Kugen Permaul, Faizal Bux, Guldhe, Abhishek., B. S. (no date) 'Advances In Synthesis Of Biodiesel Via Enzyme Catalysis: Novel And Sustainable Approaches, Renewable and Sustainable Energy', 41 (2015)1.

Tjandrajani, Anna; Attila Dewanti; Amril A; Burhany; Joanne Angelica Widjaja (2012) 'Keluhan Utama Pada Keterlambatan Perkembangan Umum di Klinik Khusus Tumbuh Kembang RSAB Harapan Kita', Sari Pediatri, 13, no.6.

WHO (2018) 'Development disabilities among children yonger than 5 years in 195 countries and territories, 1990-2016: a systematic analysis for the global barden of disease study 2016'. Zakariya, F. (2017) 'Pengaruh Pendidikan Kesehatan Dengan Media Audiovisual Terhadap Pengetahuan dan Sikap Ibu Tentang Inisiasi Menyusu Dini Di Kota Yogyakarta', Universitas Aisyiyah. 